Vol. 6 (1997): 199-205.

Research Note

\title{
Drought response of modern and old oat lines in greenhouse and long-term field trials
}

\author{
Pirjo Mäkelä, Leena Väärälä, Riikka Rajalahti, Ari Rajala, Pirjo Peltonen-Sainio \\ Department of Plant Production, Section of Crop Husbandry, PO Box 27, FIN-00014 \\ University of Helsinki, Finland, e-mail: pirjo.peltonen-sainio@ helsinki.fi
}

\begin{abstract}
This study compares the response of old and modern oat (Avena sativa $\mathrm{L}$.) lines to pre-anthesis precipitation in long-term field trials, and to pre- and post-anthesis drought in the greenhouse. Longterm field trials were carried out at the Experimental Farms of Hankkija Plant Breeding Institute and the University of Helsinki between 1965 and 1988. Grain yield of 12 oat lines (released since 1959) was compared with that of the check lines. The effect of differences in May-June precipitation on grain yield was established for different lines. Greenhouse experiments included 19 oat lines (released since 1921) and three wild species of oat (A. barbata L., A. sterilis max. L. and A. fatua L.). The data from greenhouse experiments were analysed using discriminant analysis in groups of old (released before 1970s), modern, and wild oat types. Ranking of the oat lines according to results from long-term field trials and greenhouse experiments was not consistent; contrary to the field experiments, the old lines tended to be the most drought sensitive when tested in the greenhouse. Therefore, the simple and non-laborious methods used in this study for ranking of drought sensitivity of oat lines are not recommended.
\end{abstract}

Key words: Avena ssp., cultivar ranking, drought tolerance, grain yield, physiology

\section{Introduction}

The results from long-term oat cultivar trials in Finland have indicated that grain yield has increased through plant breeding by $30-40 \%$ (Rekunen 1988, Peltonen-Sainio and Karjalainen 1991). This can be attributed to a higher grain to straw ratio following selection for short straw, and high weight and filling rate of the panicle (Peltonen-Sainio 1990). This may contribute to drought sensitivity because plant height often correlates with root depth, and most root mass of the short-strawed cultivars is concentrated in the topsoil (Mac Key 1988). Postulated changes in drought sensitivity are emphasized due to early summer drought that is characteristic in southern and south-western Finland (Mukula and Rantanen 1989).

Considerable effort has been made to develop reliable and rapid methods for screening for cultivar differences in drought tolerance. Expression of drought resistance is associated with numerous changes in plant phenology, morpholo-

(C) Agricultural and Food Science in Finland

Manuscript received November 1996 


\section{AGRICULTURAL AND FOOD SCIENCE IN FINLAND}

Mäkelä, P. et al. Drought response of oat lines

gy, and physiology (Larsson and Gorny 1988), which makes its evaluation very complex and ranking of cultivars often inconsistent. Extrapolation of drought tolerance from long-term field experiments is a rapid method for evaluating cultivar differences, but differences may be masked due to numerous factors other than precipitation which cause variation in grain yield. Comparison of grain yields produced in favourable versus drought-stressed environments, simulated in a controlled environment, possibly represents a more accurate method for evaluating differences in drought tolerance. This study compares the response of old (released before 1970s) and modern oat lines to pre-anthesis precipitation in long-term field trials and to pre- and post-anthesis drought simulated in the greenhouse.

\section{Material and methods}

Long-term field trials were carried out at Anttila $\left(60^{\circ} 25^{\prime} \mathrm{N}\right)$, Nikkilä $\left(61^{\circ} 33^{\prime}\right)$, and Viskaali Ex-

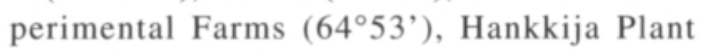
Breeding Institute, Finland, in 1965-1988 (Hankkijan kasvinjalostuslaitos 1965-1989), and Viikki Experimental Farm $\left(60^{\circ} 13^{\prime} \mathrm{N}\right)$, University of Helsinki, Finland, in 1988-1993. Grain yield ( $\mathrm{g} \mathrm{m}^{-2}$, at $15 \%$ moisture content) of eight Finnish [Hankkijan Vouti (released in 1982), Hannes (1964), Kyrö (1959), Puhti (1978), Ryhti (1970), Sisu (1948), Veli (1981), and Virma (1988)] and three Scandinavian [Pol (1974), Svea (1979), and Karhu (=Stil, 1985)] oat cultivars in addition to one breeding line ( $\mathrm{Hja} 76416)$, were compared with the long-term check lines Ryhti (1961-1973) and Puhti (1974-1988). Ratio between Ryhti and Puhti in grain yield was established with $>300$ experiments. The number of experiments included in this comparison varied between oat lines (from 70 to 200 experiments). May and June precipitation ( $\mathrm{mm}$ ) was recorded at each trial site and ranged from 40 to $188 \mathrm{~mm}$ during the study period.
Three greenhouse experiments were conducted at the Department of Plant Production, University of Helsinki, Finland. Day-length was 18 hours at light intensity (PAR) of about $200 \mu \mathrm{mol}$ $\mathrm{m}^{-2} \mathrm{~s}^{-1}$. Day and night temperatures were respectively $20^{\circ} \mathrm{C}$ and $17^{\circ} \mathrm{C}$. The same oat lines that were included in the long-term field experiments and seven additional lines [Esa (1922), Jalostettu maatiainen (1921), Kytö (1925), Osmo (1921), Pellervo (1935), and breeding lines $\mathrm{Hja} 76420$ and $\mathrm{Hja} 77200$ ] were tested in the greenhouse. Wild species of oat Avena sterilis max. and $A$. abyssinica were included in all experiments and A. fatua ('Laihia') in experiment (exp) 3. Seeds were pre-germinated on moist blotting paper for two days at $20^{\circ} \mathrm{C}$ before sowing. In total 22 pregerminated seeds were placed in a 7.51 plastic pot containing peat-vermiculite mixture $(1: 1)$. Following emergence, seedlings were thinned to 20 . The pots were fertilized by top-watering every 14 days with a nutrient solution $(500 \mathrm{ml} 1 \%$, N-P-K, Kemira Oy, Finland).

The experiments included two treatments: 1) a control, where plants were continuously wellwatered (200 to $500 \mathrm{ml}$ per pot), and 2) drought stress. When simulating temporary and moderate pre-anthesis drought (exps 1 and 2), the oat stands were subjected to a water deficit for two weeks which was followed by adequate watering until yellow ripening. When severely drought stressed (exp 3), plants were subjected to water deficit for two days close to pollination and thereafter they were slightly stressed throughout grain-fill. The severity of drought was measured using a test-tube $(\varnothing 2 \mathrm{~cm})$ to remove a soil core from each pot and determine the water content. pF-values were determined based on soil water retention curves. Physiological measurements were carried out in exps 1 and 2 at the four-five leaf stage on the two uppermost fully expanded leaves, and in exp 3 on the flag leaf close to pollination. Photosynthetic parameters were measured on two plants per treatment, three measurements per leaf, with a LI-COR LI-6200 portable photosynthesis system (Licor Inc., NE, USA). The two uppermost fully expanded leaves of six plants in exps 1 and 2 and 15 flag leaves 
Vol. 6 (1997): 199-205.

in exp 3 were collected and endogenous abscisic acid $(\mathrm{ABA})$ concentration was measured as described by Peltonen-Sainio and Mäkelä (1995). Similarly, accumulation of proline was measured as described by Troll and Lindsley (1955) and Hanson et al. (1977). Relative water content (RWC) was evaluated on three and two uppermost fully expanded leaves in exps 2 and 3, respectively, according to Ritchie et al. (1990). Mature oat plants (14 per treatment, exps 1 and 3) were cut at soil-level, air-dried, and the total weight of grains per main shoot panicle (i.e., panicle weight) of each cultivar was measured.

\section{Statistical analyses}

Average grain yields over different field trials, in which May and June precipitation differed by $\leq 5 \mathrm{~mm}$, were calculated. To establish the cultivar response to early summer precipitation in long-term field trials, the grain yield of each line was calculated relative to the check cultivar in as many experiments as possible, and the results were interpreted according to Larsson (1982). In greenhouse experiments, response of oat lines to drought was compared by calculating indices. The index of each physiological trait was calculated for each line by dividing the value for the trait measured under water deficit by that recorded under adequate watering. The greater the deviation of each physiological index from 1, the greater the response of the specific line to drought stress. The data from greenhouse experiments, arranged in a groups of old (released before 1970s), modern, and wild oat types, were analyzed by discriminant analysis (Statgraphics 1992).

\section{Results and discussion}

Differences among oat lines in response to early summer precipitation were moderate when extrapolated from long-term field trials (Fig. 1).
The regression coefficients for different oat lines ranged from -0.041 to 0.093 . Therefore, $100 \mathrm{~mm}$ decrease in May-June precipitation resulted in $4.1 \%$ higher to $9.3 \%$ lower grain yield relative to Puhti (i.e., from ca. $180 \mathrm{~kg}$ more to $400 \mathrm{~kg} \mathrm{ha}^{-1}$ less grains, respectively). Grain yields of the modern lines Hankkijan Vouti, Karhu, Pol, Ryh$\mathrm{ti}$, and Veli, were reduced more than that of the long-strawed old cultivars Kyrö and Hannes due to reduced early summer precipitation. Virma and Sisu were exceptions to this tendency. Hja 76416 is a short-statured breeding line, characterized as one of the most stable in northern growing conditions (Peltonen-Sainio et al. 1993) but showed, however, average responsiveness to early summer precipitation.

Discriminant analysis demonstrated differences among the modern, old, and wild oat types in their response to moderate pre-anthesis (exps 1 and 2) and severe post-anthesis drought (exp $3)$ simulated in the greenhouse. In $\exp 1$, the response to pre-anthesis drought was recorded immediately after the first signs of loss of turgidity and in $\exp 2$, after prolonging the effects of drought. The response of wild species ( $A$. barbata and A. sterilis max.) differed from those of the cultivated oats (Fig. 2). In $\exp 1$, this was mainly due to fewer drought-induced changes in their relative water content and stomatal conductance of the uppermost fully expanded leaf blades, in $\exp 2$, due to lower accumulation of ABA and proline, and more constant stomatal resistance and leaf temperature, and in $\exp 3$, due to more constant stomatal resistance and better ability to fill grains under inadequate watering (Tables 1 and 2). Old oat lines tended to be least able to maintain high water content during early stages of drought, but according to discriminant analysis there were no differences between modern and old lines subsequently (see exps 1 and 2 in Fig. 2). However, mean values of indices for ABA and proline content, stomatal resistance, and leaf temperature (Table 2) indicated that, in general, the modern lines were slightly more efficient than the old lines under drought stress also in $\exp 2$. When drought-stressed close to heading (exp 3), weight of grains per panicle was 


\section{AGRICULTURAL AND FOOD SCIENCE IN FINLAND}

Mäkelä, P. et al. Drought response of oat lines

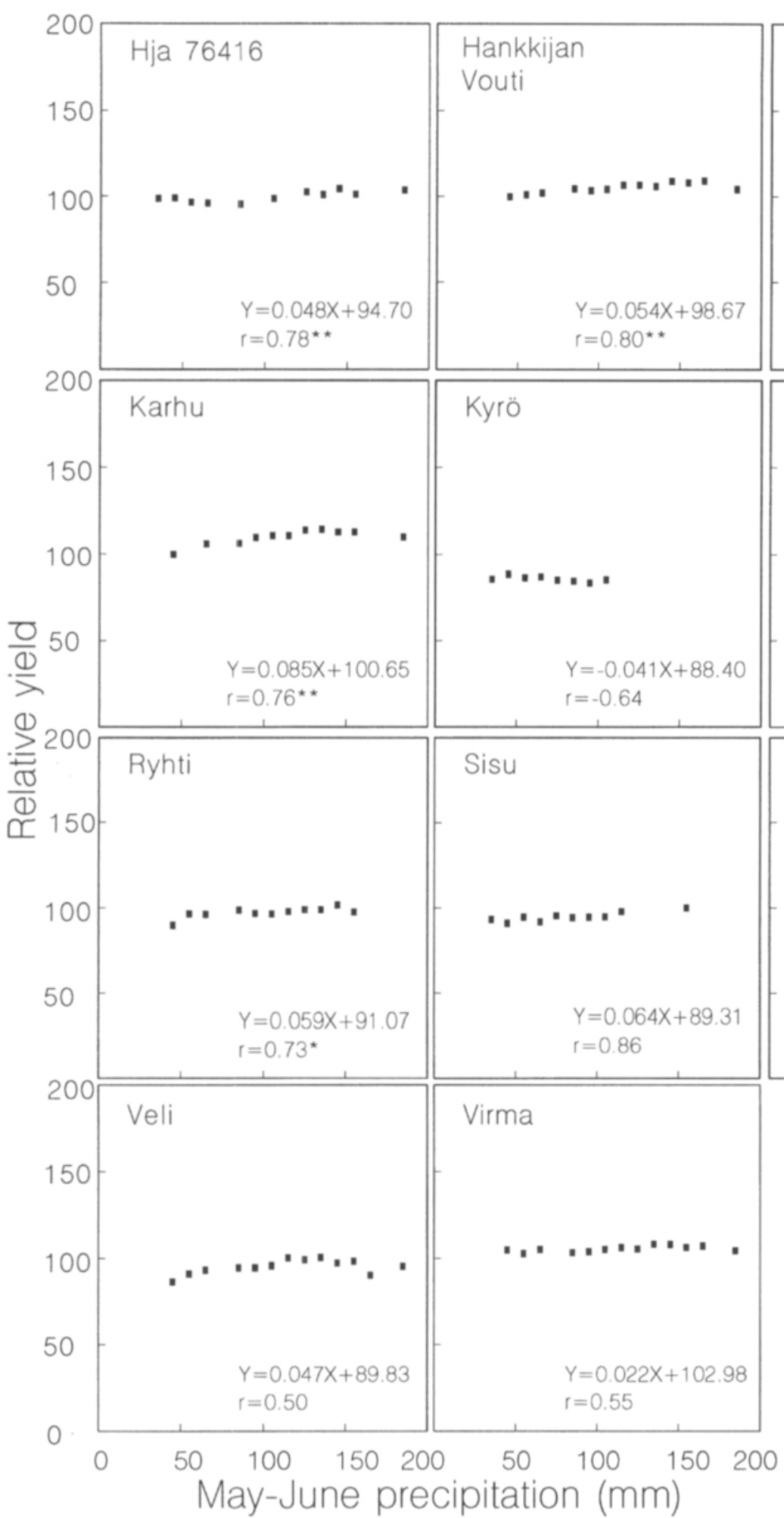

Hannes

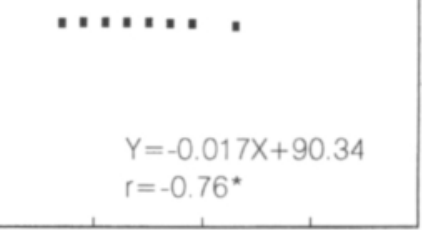

Pol

$Y=0.093 X+85.66$ $\mathrm{r}=0.85^{\star \star \star}$

Svea

$Y=0.035 X+100.51$ $r=0.87^{* * *}$

Fig. 1. Effect of early summer precipitation on grain yield of oat lines relative to long-term check cultivar Puhti. Means of grain yield for different precipitation values are calculated as running means over five successive data points. 


\section{AGRICULTURAL AND FOOD SCIENCE IN FINLAND}

Vol. 6 (1997): 199-205.

Table 1. The results of discriminant analysis for indices of morpho-physiological traits in modern and old oat cultivars and wild species of oat.

\begin{tabular}{|c|c|c|c|}
\hline \multirow{2}{*}{\multicolumn{2}{|c|}{ Indices\# }} & \multicolumn{2}{|c|}{ Standardized coefficient } \\
\hline & & DF1 & DF2 \\
\hline \multirow[t]{7}{*}{ Exp 1: } & PWEI & 0.44 & -0.69 \\
\hline & ABAI & 0.57 & -0.20 \\
\hline & RWCI & 1.40 & 0.22 \\
\hline & CERI & 0.55 & 1.31 \\
\hline & RESI & 0.32 & 0.57 \\
\hline & CONI & -0.87 & -0.55 \\
\hline & TEMI & 0.10 & -0.25 \\
\hline \multicolumn{2}{|c|}{ Relative percentage } & 72.8 & 27.2 \\
\hline \multicolumn{2}{|c|}{ Significance level } & 0.003 & 0.068 \\
\hline \multirow[t]{8}{*}{ Exp 2: } & PWEI & 1.70 & 0.89 \\
\hline & ABAI & -5.43 & -0.14 \\
\hline & PROI & 6.67 & -0.77 \\
\hline & RWCI & 2.77 & 0.56 \\
\hline & CERI & -2.98 & 0.11 \\
\hline & RESI & 4.68 & 1.30 \\
\hline & CONI & 1.05 & 2.30 \\
\hline & TEMI & 4.94 & -1.74 \\
\hline \multicolumn{2}{|c|}{ Relative percentage } & 89.3 & 10.7 \\
\hline \multicolumn{2}{|c|}{ Significance level } & 0.012 & 0.494 \\
\hline \multirow[t]{7}{*}{ Exp 3: } & PWEI & 8.83 & 2.77 \\
\hline & ABAI & -5.00 & 8.97 \\
\hline & PROI & -1.72 & -3.00 \\
\hline & CERI & -1.01 & 3.68 \\
\hline & RESI & -8.04 & 1.61 \\
\hline & CONI & 4.06 & -6.48 \\
\hline & TEMI & -1.65 & 5.24 \\
\hline \multicolumn{2}{|c|}{ Relative percentage } & 93.9 & 6.1 \\
\hline \multicolumn{2}{|c|}{ Significance level } & 0.050 & 0.855 \\
\hline
\end{tabular}

\# indices for RWCI, relative water content; CONI, stomatal conductance; ABAI, abscisic acid concentration; PROI, proline concentration; RESI, stomatal resistance; TEMI, disparity between air and leaf temperatures; PWEI, panicle weight

most reduced in the modern cultivars, but differences between the modern and old cultivars were modest. A. fatua did not shown any signs of improved drought tolerance.

Larsson (1982) and Larsson and Gorny (1988) concluded that the most reliable ranking
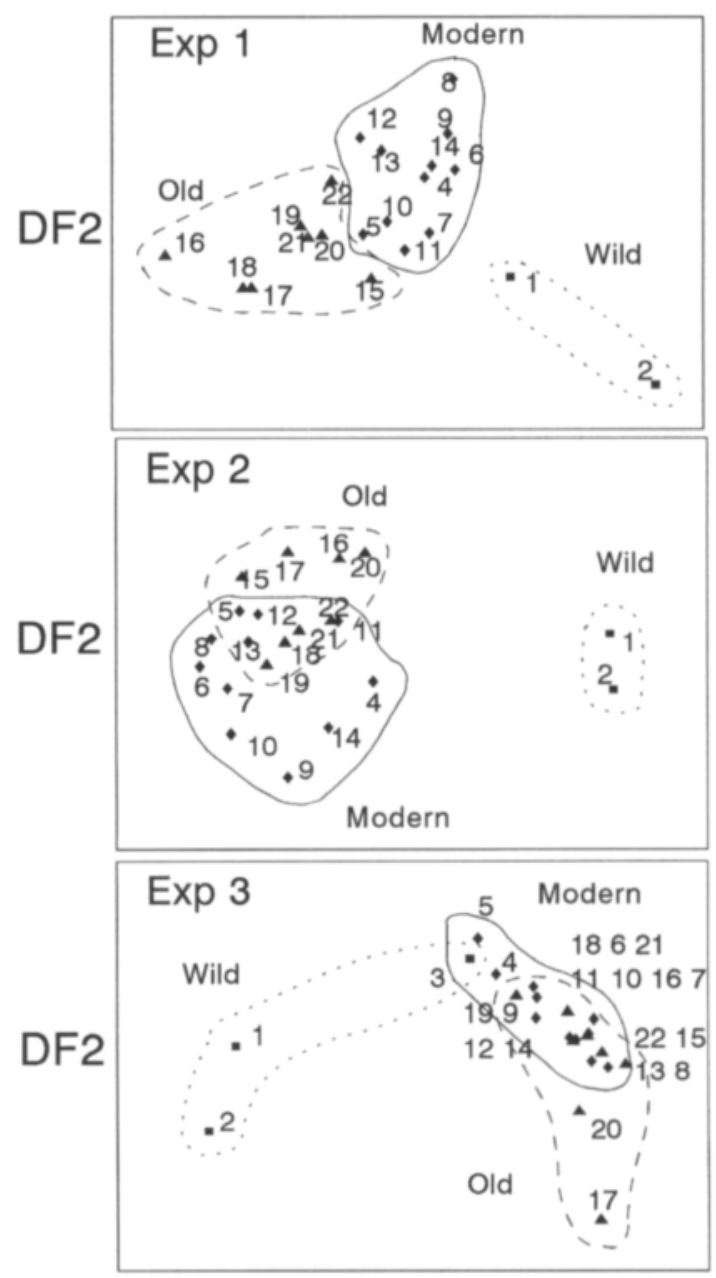

\section{DF1}

Fig. 2. Discriminant analysis plots for old, modern, and wild oat types. Discriminant functions, DF1 and DF2 are characterized in Table 1. Wild oat: $1=A$. abyssinica, $2=A$. sterilis max., $3=A$. fatua (exp 3 solely); Modern: 4=Hankkijan Vouti, $5=\mathrm{Hja}$ 76416, 6=Hja 76420, 7=Hja 77200, 8=Karhu, 9=Pol, 10=Puhti, 11=Ryhti, 12=Svea, 13=Veli, 14=Virma; Old: $15=$ Esa, $16=$ Hannes, $17=$ Jalostettu maatiainen, $18=$ Kyrö, 19=Kytö, 20=Osmo, 21=Pellervo, 22= Sisu.

of oat lines according to their response to water deficit is established by combining the results from field trials and greenhouse experiments. However, ranking of the oat lines according to long-term field trials and greenhouse experiments differed. For example, Hannes and Kyrö 
Mäkelä, P. et al. Drought response of oat lines

Table 2. Mean values of indices with highest loadings according to discriminant analysis for modern, old, and wild oat types. The greater the deviation of each index from 1, the greater the response of the specific oat type to inadequate watering.

\begin{tabular}{rlccc}
\hline \multirow{2}{*}{ Indices\# } & \multicolumn{3}{c}{ Oat type } \\
\cline { 3 - 4 } & & Modern & Old_ & Wild \\
\hline & & 0.83 & 0.99 \\
Exp 1: & RWCI & 0.92 & 0.09 & 0.15 \\
CONI & 0.14 & 3.67 & 0.80 \\
Exp 2: & ABAI & 2.70 & 93.25 & 8.24 \\
PROI & 89.07 & 8.49 & 1.26 \\
RESI & 7.24 & 0.19 & 0.56 \\
TEMI & 0.25 & 0.42 & 0.67 \\
Exp 3: & PWEI & 0.36 & 15.00 & 2.08 \\
RESI & 7.81 & & \\
\hline
\end{tabular}

\# indices for RWCI, relative water content; CONI, stomatal conductance; ABAI, abscisic acid concentration; PROI, proline concentration; RESI, stomatal resistance; TEMI, disparity between air and leaf temperatures; PWEI, panicle weight

identified as the most drought tolerant oat lines according to field trials, were among the most sensitive lines (exp 1) or were of average performance (exps 2 and 3) when tested in the greenhouse. Probably the main reason for the inability of the old cultivars to cope with pre-anthesis drought when tested in the greenhouse, is that growing them in pots masks the effect of root depth as a tolerance mechanism. However, evidently it is difficult to rank cultivars reliably based solely on the results from field trials, despite some differences in response of oat lines to pre-anthesis precipitation. Numerous factors other than precipitation cause variation in grain yield. This is possibly emphasized when testing modern cultivars solely and lacking such large intrinsic differences in plant stand structure as included in this study. Furthermore, comparing drought response of the most recently released cultivars may be restricted due to too few data points. Therefore, the simple and non-laborious methods represented in this study seem to be biased and are not suggested for use when ranking drought tolerance of oat lines.

Acknowledgements. The authors are grateful to professor Erkki Kivi and director general Voitto Koskenmäki for kindly allowing us to use the data from field trials carried out at Hankkija Plant Breeding Institute

\section{References}

Hankkijan kasvinjalostuslaitos 1965-1989. Trial Results. Rekunen, M. (ed.). Hankkija Plant Breeding Institute. Hanson, A.D., Nelsen, C.E. \& Evertson, E.H. 1977. Evaluation of free proline accumulation as an index of drought resistance using two contrasting barley cultivars. Crop Science 17: 720-726.

Larsson, S. 1982. A simple, rapid and non-destructive screening method useful for drought resistance breeding in oats (Avena sativa L.). Zeitschrift für Pflanzenzüchtung 89: 206-221.

- \& Gorny, A.G. 1988. Grain yield and drought resistance indices of oat cultivars in field rain shelter and laboratory experiments. Journal of Agronomy and Crop Science 161: 277-286.

Mac Key, J. 1988. Shoot:root interrelations in oats. In: Mattsson, B. \& Lyhagen, R. (eds.). 3rd International 
Vol. 6 (1997): 199-205.

Oat Conference. Lund, Sweden, July 4-8 1988. Svalöf, Sweden. p. 340-344.

Mukula, J. \& Rantanen, O. 1989. Climatic risks to yield and quality of field crops in Finland. VII. Oats 19691986. Annales Agriculturae Fenniae 28: 37-43.

Peltonen-Sainio, P. 1990. Genetic improvements in the structure of oat stands in northern growing conditions during this century. Plant Breeding 104: 340-345.

- \& Karjalainen, R. 1991. Genetic yield improvement of cereal varieties in northern agriculture since 1920. Acta Agriculturae Scandinavica 41: 267-273.

- \& Măkelă, P. 1995. Comparison of physiological methods to assess drought tolerance in oats. Acta Agriculturae Scandinavica 45: 32-38.

- Moore, K., \& Pehu, E. 1993. Phenotypic stability of oats measured with different stability analyses. Journal of Agricultural Science, Cambridge 121: 13-19.

Ritchie, S.W., Nguyen, H.T. \& Holaday, A.S. 1990. Leaf water content and gas-exchange parameters of two wheat genotypes differing in drought resistance. Crop Science 30: 105-111.

Rekunen, M. 1988. Advances in the breeding of oats, comparative trials with historical varieties in 197787. Journal of Agricultural Science in Finland 60: 307321.

Statgraphics 1992. Statistical Graphics System, Version 6.0.

Troll, W. \& Lindsley, J. 1955. A photometric method for the determination of proline. Journal of Biological Chemistry 215: 655-660.

\title{
SELOSTUS
}

\section{Vanhojen ja uusien kauralajikkeiden reagointi kuivuuteen kasvihuone- ja peltokokeissa}

\author{
Pirjo Mäkelä, Leena Väärälä, Riikka Rajalahti, Ari Rajala, Pirjo Peltonen-Sainio \\ Helsingin yliopisto
}

Kasvinjalostus ja tutkimus kaipaavat nopeita ja yksinkertaisia menetelmiä kuivuudensiedon arvioimiseksi. Tutkimuksessa verrattiin vanhojen (laskettu kauppaan ennen vuotta 1970) ja uusien kauralajikkeiden kuivuudenkestävyyttä monivuotisten peltokokeiden ja kolmen kasvihuonekokeen perusteella.

Peltokokeissa kunkin lajikkeen jyväsato laskettiin suhdelukuna mittarilajikkeisiin. Kokeet jaettiin eri ryhmiin touko-kesäkuun sademäärän perusteella ja kullekin ryhmälle laskettiin suhdeluvun keskiarvo. Touko-kesäkuun sademäärän vaikutusta lajikkeiden suhteelliseen jyväsatoon kuvattiin käyrillä. Kasvihuonekokeissa kauralajikkeet altistettiin kuivuudelle pensomisvaiheessa tai röyhylle tulon yhteydessä. Lajikkeiden herkkyyttä reagoida kuivuuteen verrattiin fysiologisten ominaisuuksien perusteella lasketuista indekseistä (kuivuusstressioloissa saatu tulos jaettuna kontrollikoejäsenen tuloksella). Mitä enemmän in- deksi poikkesi arvosta yksi, sitä voimakkaammin kyseinen lajike reagoi kuivuuteen.

Peltokokeet osoittivat, että useat uudet lajikkeet reagoivat vanhoja herkemmin alkukesän kuivuuteen. Virma ja Sisu olivat poikkeuksia. Kasvihuonekokeiden perusteella vanhojen ja uusien lajikkeiden erottelu oli vaikeaa ja suuntaus näytti olevan jopa päinvastainen kuin peltokokeissa. Kasvihuonekokeessa kaurat kasvatettiin 7,5 litran purkeissa, jolloin syväjuurisuus kuivuudensietomekanismina jäi huomiotta. Myös peltokokeista saatu tieto lajikkeiden reagoinnista alkukesän sademäärään saattaa olla harhainen, koska sademäärän lisäksi useat muut tekijät vaikuttavat sadontuottoon. Koeaineiston tuleekin olla laaja luotettavan käsityksen saamiseksi, mikä usein rajoittaa jalostusaineiston kuivuuden siedon arvioimista. Näistä syistä tässä tutkimuksessa käytettyjä yksinkertaisia menetelmiä ei voida suositella käytettäväksi lajikkeiden kuivuusherkkyyden selvittämiseksi. 